\title{
Privatization Policy of Hydrocarbon Sector was Not Effective
}

\section{Vladimir Mici}

\section{Doi:10.5901/mjss.2014.v5n13p446}

Lecturer in Mediterranean University of Albania

\section{Abstract}

This article aims to reflect, economic policies applied and their effects in the hydrocarbon industry during the period of 1990-2014. In the context operations are made out to reform the sector. These policies has aimed the achievement of objectives for liberalization of the sector and encouraging foreign direct investment, to have an impact overall economy and petroleum sector in particular. The purpose of this analysis is to see the effect of these policies and the economic impact reflected in the policies of the government. Through the analysis shows how it has impacted on economic growth, tax policy and employment.

Keywords: Privatization, Albetrol, ARMO, hydrocarbons, eficiense, Tax and HDI.

The privatization of the Albanian economy began in 1991 initially with separated capital separate and later affecting industries and other branches of the economy, the weight and importance of which was growing and that constituted an essential element of economic development in the future.

Despite the official statement describing a series of legal and sub-legal acts, the truth is that important nonstrategic sectors passed very quickly under a privatization, where the rules of the game were often not respected and therefore unjust enrichment process came under a great attac of counter-accusations, where politics had its own goals for political capital. Many of these other companies privatizations took place, many of them changed their destination and many of them disappeared leaving no sign.

The most profitable process of privatization was the privatization of houses. People got their homes, some of them transformed and turned into businesses, some of them were lost as a result of abandonment of cities built by the system. However, if there is an industry that has give a lot to the country's economy are apartments. They gave rise to the development of the construction industry, playing with the hunger for comfortable houses, the need of small business, which can be maintained with little money, and had great mitigation conditions of the state.

Errors were large because the property passed into the hands ineffective manager, inexperienced and often without proper training and were few of them, who benefited from caos the privatization of economic.

Albanian State in 1998, after taking some legal steps to protect state property, sanctions the privatization strategic sector, including the hydrocarbon system, therefor oil cycle Up, med and down stream.

First legal Amendment was the detachment of this small sector of commerce by transfering this totally to the private sector. The second step was CMD No. 756 to create separate companies for research of oil extraction, processing and sale of its derivatives in huge quantities and oil services company.

In this phase scientific research center of oil and gas was also separated, passing under the Ministry of Economy. The reason for such a division was the large fragmentation of the sector and creation of companies that can survive separately. Experience showed that with the exception of two companies, none of them managed to survive. And they both remained tied up at the moment, when one of them finally passed state owner.

What distinguishes this from other industries, not just the fact that they present an integrated system, but also the fact that their connections were multiple and created in 50 years, when they are faced with challenges that dictatorship was required to perform.

Their 50 years old result was that they created and kept an army of 45 thousand employees, they had created three towns of employees, have created a more modern infrastructure than others and had developed a generation of very good technocrats, and that for the sake of truth with the tools and the conditions they had, for whom it is an honor to speak.

Privatization was seen as a necessary tool for the new economic system. Since the late 80 s, the industry was experimenting with concession contracts, directing research in the sea. In the years 1992-1998, it experimented and introduced privatization of sectors, which it is not considered strategic for the development of the hydrocarbon sector. Over 15 enterprises and the assets were sold quite large. 
They left from the system two cargo parks cargo, a bus transportation park, three enterprises buildings, three special service enterprises, drilling activity was riconstructed from 6 to 1, one seismic undertaking was liquidated and two oil refineries. It reduced activities within other units. The contraction reached that number of strategic workforce fell to 15 thousand employees and this plans required time, even in these conditions had more workforce.

What stigmatized this scenario was continuous production decline, because they eliminate all forms which can intensify increase or maintain current levels of production. This fact increased the absence of strict laws for the administration of state property, accompanied with high costs of production and sales.

Besides all this performance, then its not even stay policy, which had seen these sectors as sectors that could extend its employment policy and collection militant vote for their power.

Being stuck between a political moral degradation on the one hand and law enforcement on the other hand, the negative effects on management present the ups and downs from the phase in which administrators and politicians feared implementation of the law. This situation has created a situation almost ridiculous with state property were the laws look beautiful on paper and the application is careless. Under this chaos started and continued the process of privatization.

By privatizing the government intends to achieve several goals, whose effects are measurable and comprehensible.

1- To achieve accountant provide additional budgetary resources through ownership change.

2- To reach as better manage this property away from abuse and the theft, which were made social property.

3- To increase the level of tax inflows into the budget.

4- To raise the level of employment and individual revenues.

5- To influence on the economic growth of the country.

The hydrocarbon industry is not just a fasson industry,but an industry, which implies economic growth and has amplifiered, engaged in work and income level.

Beyond theoretical bases, the practice in this industry is a double-edged sword.

Was the revenue growth affected by a failed privatization?

Hydrocarbon sector privatization can be conceived and implemented in two forms.

a- The form of privatization and managing part here obtain the government agreements with multinational oil companies, which take on the management of the existing fields and apply them investment in of the latest technology. As a consequence have increased the oil-extraction, increasing reserves and production growth, which in the final analysis, lead to revenue growth. This is the case the passage of oil oilfields in the hands of multinational companies. This in the form of contracts with production. The division was and remains a form of foreign direct investment (FDI).

b- The classic form of privatization or selling the control of wealth. In this case we change the form of ownership, and this is the case of ARMO Company sha.

In Albania the process of transition them is different. The first process is the result of Bilateral agreements and not auction. While the second case is the result of an auction.

The main distinction that which differs is the fact that after some time the state restores the property to himself, while in the second case no. It should be noted that this return is also accompanied with consequences left by the utilization of natural resources. With current rates of extracting turns out that Albania after 25 years will say goodbye to existing reserves.

Another crucial distinction is the selling price of such property. Unlike the classical privatization, where the buyer pays the entire amount, here buyer pays only the management bonus, which can be a bonus signature or production bonus. Lower values under $\$ 1$ million show that this process has been compromised.

In the form of the sale of wealth, as the case legally ARMO was seeking a subject with potential technical, managerial and financial. According to the contract the buyer for the period 2008-2013 will commit the modernization by investing 250 million euros. The facts indicate otherwise. Society is collapsing with inability to pay, with multiple debts and no case has shown the technical potential. So this is not about investing, although the monopole was approved for the first year of trading of D2 diesel on the market,by removing this right illegally,by Constitutional Court.

What happened to the production and processing of the crude oil?

1- Production of crude oil has increased at the national level. Processing of crude oil at the national level is decreasing. So is noticed growth of crude oil for export and import growth of crude of oil byproducts.

As seen from the table, since 2005 when it started PSC (production sharing contracts) with Bankers and than accompanied by ARMO sha privatization, resulting the following information:

Source: Department of Customs Albania 


\begin{tabular}{|c|c|c|}
\hline \multicolumn{3}{|c|}{ Albanian oil exports abroad for the periode 2005-2012, in value and quantity } \\
\hline Year & Amount (All ) & Quantity (ton) \\
\hline 2005 & $1,903,109,235.00$ & $79,119.01$ \\
\hline 2006 & $3,293,554,203.00$ & $138,648.75$ \\
\hline 2007 & $7,362,170,546.00$ & $260,278.27$ \\
\hline 2008 & $10,037,775,827.00$ & $276,850.85$ \\
\hline 2009 & $12,067,423,717.00$ & $370,013.02$ \\
\hline 2010 & $29,044,294,085.00$ & $571,172.24$ \\
\hline 2011 & $41,723,328,212.00$ & $750,636.28$ \\
\hline 2012 & $56,725,307,763.00$ & $1,023,795.34$ \\
\hline
\end{tabular}

Albanian production in 2005-2013

\begin{tabular}{|c|c|c|c|c|}
\hline \multirow{2}{*}{ Year } & Europe & Albania & \multirow{2}{*}{ \% to europian production } & Albania \\
\cline { 2 - 3 } & $\mathrm{bbl}$ & $\mathrm{bbl}$ & & $\begin{array}{c}\text { Ton metrik } \\
\text { 1TM=7.3bbl }\end{array}$ \\
\hline 2005 & $2,250,641,640$ & $2,549,492$ & 0.11 & $349,245.50$ \\
\hline 2006 & $2,107,765,661$ & $2,852,136$ & 0.14 & $390,703.50$ \\
\hline 2007 & $1,987,637,485$ & $2,372,956$ & 0.12 & $325,062.50$ \\
\hline 2008 & $1,894,512,305$ & $2,203,242$ & 0.12 & $301,814.00$ \\
\hline 2009 & $1,818,785,463$ & $1,967,748$ & 0.11 & 269554.50 \\
\hline 2010 & $1,696,072,937$ & $3,968,671$ & 0.23 & $543,653.50$ \\
\hline 2011 & $1,558,166,797$ & $5,673,673$ & 0.36 & $777,215.50$ \\
\hline 2012 & $1,452,468,528$ & $6,155,835$ & 0.42 & $843,265.00$ \\
\hline 2013 & $1,386,556,470$ & $6,218,673$ & 0.45 & $851,873.00$ \\
\hline Totali & $16,152,607,285$ & $33,962,425$ & 0.21 & $39,102,960$ \\
\hline
\end{tabular}

If we compare the data show that during the periode of 2010-2013, oil processing in Albania turns out in minimal levels. Regardless to whom the source above is referred there are uncertainties concerning quantities produced it results that the companies contracted by the Albanian government have produced oil abroad, becoming a source that contribute negatively to the economic growth and reduce the weight of job sector and the encouragement of employment that connects this industry.

Can the foreing companies be guilty ,foreign companies, when those that initially have created the luxury to export or Albanian oil extracted ? No ,foreign companies have seen their interest fairly narrow by creating possible spaces of evasion via transfer pricing or the purchase of services or foreign investment with a very high cost. Who is the cause that the number of employees has decreased? To illustrate the latest fact, resulted wage differentials as well as for the services rendered by foreign or domestic. Transferring the capital abroad for free or unobstructed , the tax administration inability for strict control, create spaces of abuse.

Observing Bankers Petroleum's balance sheet shows that by $100 \%$ of the total revenue realized from oil produced it pays 10\% mineral endowment , $6 \%$ pre-existing and $1 \%$ diesel won to the state or Albetrolit (the state company oil),so for the years 2011, 2012, 2013 has been entitled to $83-84 \%$ of all the oil out. This situation, added the fact that all is exported aaccompanied with a reduction of processing capacity in the country.

The oil import data show that imports quantity has increased with a stabilization in the latest 3-4 years for overcoming the price, indicating a rebound in demand to the price effect.

\section{Employment}

Does that privatization realized the employment effects? Development of the area is characterized:

- In an indirect bearing which evaluates the impact of the exploitation of hydrocarbons in employment, income residents in these areas and in the final evaluation of economic benefit.

- Link benefits forced that measure the impact of income derived from this activity directly or indirectly to increased economic level of the area.

These links of economy and the exploitation of hydrocarbons estimated economic parameters which are called multiplier factors. The parameters more used to evaluate the impact of external factors in the economy are:

1. Benefit multiplier implies the growth of the total value of production in all branches of the economy as a result of the exploitation of hydrocarbons in the area up to one entity (the parameter used in the multiplier). 
2. Multiplication of revenue size examines the impact of income benefiting from workers employed in hydrocarbon exploitation activities considering the indirect effects on the economy.

3. Factor employment multiplier estimates the number of job vacancies and those that arise indirectly as a result of exploitation of hydrocarbons in oil-bearing areas and its processing.

Based in world literature follows that direct and indirect impacts during the use of hydrocarbons to create Vacancies, to increase the income of residents and the public are of major importance. Some concrete data on the importance of this industry in the economy of a country that characterized for rich oil resources, as provided by the U.S. PWC study (2011). Based on this study:

For the year 2009, from industryof use of hydrocarbons were created 9.2 million vacancies direct or indirect means. $5.3 \%$ of the employment opportunities.

- The income that were profited directly or indirectly from this branch were $\$ 534$ billion (approximately $6 \%$ of revenues). Analikisht employed directly in the exploitation of hydrocarbons and its processes totaled 2.2 million. 477,000 of them worked in research and in exploitation of oil-bearing layers 79,000 for various drilling made in these areas.

- 226,000 employees at its research of shale oil layers. The general revenues of employees working in these branches amounted to $\$ 80$ billion and total value reached $\$ 175$ billion.

Based on these data follows that:

1. The employment multiplier factor is approximately 4.2 meaning that for every new job created in the branch there are 3.2 vacancies in the economy of the country.

2. Likewise 3.2 multiplier value of income that goes to $\$ 1$ a worker who receives directly from the industry gained $\$ 2$ more for workers in other branchesand for every $\$ 1$ increase in the value of production increases value of $\$ 1.3$ production throughout the economy.

Also the benefits of the state itself are enormous. Entities, except for taxes paid for other services (property tax, property transfer).

In Colorado in 2007 has become a study (CERI 2007) the indicator of employment multiplier is 3.4 of the research branch for carrying oil layers and their exploitation, while gaining 1.31 multiplier factor. Oklahoma (OSU, 2008) multiplication factors of employment and profitability were evaluated at 4.22 and 1.75 .

Exponential multiplication factor for vacancies amounted to 3.65, meaning for every vacancy created by the activities offered 2.65 vacancies in all sectors of the economy. Factor indicator of income multiplier was 2:57, ie for every $\$ 1$ of direct benefit from the work of the employees in the sector gained $\$ 1.57$ to the economy.

An extensive literature with examples from many states provide information on the positive and negative impact of the use of hydrocarbons in the area's economy and the country. Various hypotheses suggest that the exploitation of hydrocarbon industry and other natural assets do not always have a positive part in social and economic development in many countries not so much developed, not because the use and heavy equipment where exploitation of natural resources occurs.

As a support to this theory is the poor economic situation the countries rich in natural treasures of Africa, while the economically strong countries such as Korea and Japan are of poorest from natural resources.

However being supported by some researchers (Davis, 1998, Ahammad \& Clement, 1999, Clements \& Johnson, 2003) the negative impacts from the use of hydrocarbons in some cases should not be generalized.

In many countries that are being developed, or so-called developed countries, exploitation of hydrocarbon and natural gas plays a important role in providing opportunities for foreign investment, export growth by improving the balance of the import-export of the country. Exploitation of hydrocarbon affected positively on the economic development of Botswana, Morocco, Namibia and South Africa, but not for Sierrena Leone, Zambia and Liberian.

Often the exploitation of hydrocarbon industry has not profitable results for society and the state in the countries in transition, of the reason for political situation in the these countries (eg not funcioning democratic ideology, corruption the phenomenon etc..) and for this reason comes not a good exploitation and appropriate of natural resources of the country (Moore, 2001).

Based on these studies and in world different experiences to we can not create a correct theory, or obtain a correct and argued answer to question whether a hydrocarbon activities will be to the benefit of society of for the benefit of economy of that country, because every case is unique. As highlights in his study Pedro (2004) the question should not be formulated if there should be or not the exploitation of hydrocarbons but how to do this exploitation and what criteria must accomplished that this industry can have a positive impact on the economy of the country and be beneficial to society.

Being concentrated on the Albanian reality, economic development model will precisely determine the importance 
of developing the industry's of exploitation of hydrocarbons and other natural resources. Development options that are mentioned often support the cost of cheap labor, the development of economy based on knowledge , economic development based on natural advantages that give us the geographic location, among which are the richest oil-bearing layers.

Often the cheap labor, which is confirmed by global experience, there is not a strong factor to have a competitive economy. Precisely this economy is not competitive in poor countries and in those in which labor time is cheap. Also even though the country where the policy applies to cheap labor force, becomes attractive to foreign investment, economic development would not be in favor of the majority of the population, on the contrary, economic development based on knowledge, influences positively the competition by increasing the average income at national level and by improving life standards of the society.

Evaluating the positive aspects of using natural resources of a country is noticed that this selection influences for sustainable development by affecting the growth of the national economy, increase competitiveness, and the improvement of Standards of life for different layers of the population.

A positive factor of the use of natural resources is that this branch represents a steady competition, for reasons that it can not be transferred anywhere. In this branch, positive impact includes not only the national economy but it is also a opportunity for the country of huge investments of foreign (due to the nature of the investment), for better incomes for workers, increase of the possibility to export, the benefits from various state tax etc.. Also plays an important role at strengthening of the country geopolitical, because natural resources are limited geographically. This is more for hydrocarbons, the role played by these natural resources for the benefit of energy which is a global problem.

In theory these conclusions lead us to the fact that these levels of oil extraction,Albania should not have been with a $71 \%$ debt and $17 \%$ unemployment by the end of 2013.

The fact that investments in this branch which except high salaries and the circle should have direct placements has only one conclusion. According to Bankers the aid activity performing other service companies employ 1,600 people. While the number of employees for the company is 458 employees. According to this fact turns out that this investment has report to those directly employed and indirectly by 1 direct employees to 3.5 employees indirectly. This conclusion of Bankers seem exaggerated, but it does not say that Bankers how many thousand dollars they invest in a new job.

If we consider the key personnel of the company, which includes nearly $50 \%$ of the salary and $50 \%$ of the foreign subcontractors firms turns out that all of their analysis does not stands in theory.

Normally we would have positive effects on the economies of the area, its infrastructure realizing new construction in the road network, employment for the area residents and secondary organizations raising that will be required, preparation of specialists for different processes of exploitation, who will be able to work abroad with the acquired experience, interconnection that this branch will have with other branches of different activities and that gives them the opportunity of development .

The infrastructure and poverty level of these areas has increased. This is explained by the fact of lowest fiscal burden of the local residents, at a national level.

\section{Tax Effects}

Judgment on the tax effects should be seen in the economic context. Hydrocarbon industry is among the industries that throughout its global history, but also Albanian, undergoes a continuous growth of the fiscal burden. This becomes more evident after the 90s. Until 2003 APC State Corporation (contribute 65\% state tax . tax pay in from one operating business in the hydrocarbon field with a fiscal burden that had contributed about $6-7 \%$ in budget state). This weight was higher in 90 years, because the state benefit on average $70 \%$ of the the production value.

Salaries of employees occupied $50-60 \%$ of the costs, directly affecting the increase of aggregate demand. While it was also a considerable source of revenues in the form of _income from tax, social security and health. If there is one sector where the effect of shock therapy was felt less was this industry that survived the competition and confronted the absence of laws, despite of high corruption that accompanied this period. Until 2008, the industry did not apply mineral endowment.

This has led to increased budgetary revenues due to new tax legislation. Up to 1998, all contracts with anticipated production division $50 \%$ cost coverage, which meant that the state had passed Isaiah, the title certainly worth $30 \%$. This made the company because Premier Oil, the company that had taken Patos exploitation Navy to declare failure and move on. While the company took advantage of a legal space where bankers cost coverage was up to $100 \%$ of the of the final costs opex and capex. There is not an explanation that instantly with its departure, Bankers took her place.

Observing the progress of taxes, the tax basic that pay the foreign societies is the royalty, because the firms are 
currently covering their capex. Only $1 \%$ of extracted oil revenue goes to the state. Cluster of royalty has marked progress This is due to high production levels and 2.5 multiplicator of the price of crude oil. This becomes more apparent in 2008, when prices jumped over 2 times.

\begin{tabular}{|c|c|c|c|c|c|c|c|}
\hline \multirow{2}{*}{ No } & \multirow{2}{*}{ Subject } & \multicolumn{6}{|c|}{ Royalty 0001\$ } \\
\cline { 3 - 8 } & & 2009 & 2010 & 2011 & 2012 & 2013 & Total \\
\hline 1 & Bankers & 20,468 & 33,682 & 63,941 & 78,361 & 94,294 & 326,979 \\
\hline 2 & Albetrol & 3,309 & 7,617 & 4,032 & 9,491 & 6,087 & 30,536 \\
\hline 3 & Stream Oil & 396 & 597 & 1,616 & 1,666 & 2,620 & 6,895 \\
\hline & Total & 24,172 & 41,896 & 69,139 & 89,518 & 103,001 & 369,410 \\
\hline
\end{tabular}

And as marks an increase royalty, VAT marks a drastic decrease because ,foreign companies were excluded from paying VAT on services in Albania and also for export sale is excluded from. This is a complicated situation, because in this case the state makes balancing with imported -products, but did not recover the revenue that Social Security had to deal from processing, TAP, other local taxes and special. And finally the effects of depreciation of the national currency and the decrease of purchasing power in the country,

This day there are employees who have not received salaries over 4 months, foreigners who are paid 30 times more (although the law sets limits 1; 7 minimum wage and moreover there is a tendency of lowering wages, as is the case ARMO sha. number of employees has had a strong tendency of decrease, which was felt more in the early years 1992-1998 and then this sector has constantly been at the center of the political cyclone, the replacement of powers. Nevertheless the trend has been decrease .

Referring to the progress of the number of employees in 2005 we have:

\begin{tabular}{|c|c|c|c|c|}
\hline No & company & year2005 & year 2013 & difference \\
\hline 1 & Albpetrol Sha Patos & 4,038 & 1,890 & $-2,148$ \\
\hline 2 & Armo Sha & 2,200 & 1,500 & -600 \\
\hline 3 & Servcom Sha & 375 & 0 & -375 \\
\hline 4 & UMN Patos shpk & 90 & 0 & -90 \\
\hline 5 & UMN Kuçovë Shpk & 228 & 0 & -228 \\
\hline 6 & Bankers & 211 & 458 & +247 \\
\hline 7 & Instituti Naftes & 106 & 0 & -106 \\
\hline 8 & Stream Oil & & 123 & +123 \\
\hline 9 & IEC Visoka & 7,020 & 77 & +77 \\
\hline & Totali & 4,048 & $-2,972$ \\
\hline
\end{tabular}

As shown are lost jobs not least but 3000 employees.

It should be noted, the economic strategy, decrease of state role in economy, should bring at higher rates opening of new jobs and higher wages. In fact the phenomenon is reversed.

If we refer to the U.S. economy in the field of hydrocarbons, it is running "full gas", where it provides $84 \%$ of its needs and one of the indices is that they see how this branch of industry generates extra jobs or closes. The level of generation of these countries is the basis of why this country has progressed and is the engine of job openings countries. Our model does not generate jobs, therefore we can say that we had a a failed privatization.

Increase of production has served to increase exports and increase foreign equity returns. Today most of the services in this sector are carried out from foreign companies subcontracted by concessionary companies, closing the door of technological innovation mechanical bases, drilling activity and special works. Though these have been at cost 23 times lower.

Fiscal leverage haven't served as a premium for growth. Observing the economic growth, that while the extractive industries grow at high rates, processing industry continues _ into decline. For the period 2010-2013, although growth rates in extractive industry are $25 \%$, processing industry continues its deterioration with a decline of $3.23 \%$ where the main role is played by the oil processing industry, construction sector as $4.82 \%$ and supportive services $25.3 \%$.

The effect becomes even clearer when we compare its extractive industry with hydrocarbon extraction industry in particular. In this case there is a lower rate. 


\begin{tabular}{|c|c|c|c|}
\hline Year & Production of brut oil & Rate of Growth \% & Rate of Extraction \% \\
\hline 2,005 & $349,245.50$ & & -0.66 \\
\hline 2,006 & $390,703.50$ & $+11,87$ & 31.07 \\
\hline 2,007 & $325,062.50$ & -16.8 & 36.42 \\
\hline 2,008 & $301,814.00$ & -7.15 & -9.87 \\
\hline 2,009 & 269554.50 & -10.68 & 38.21 \\
\hline 2,010 & $543,653.50$ & +101.69 & 39.03 \\
\hline 2,011 & $777,215.50$ & +42.96 & 21.30 \\
\hline 2,012 & $843,265.00$ & +8.5 & 16.05 \\
\hline 2,013 & $851,873.00$ & +1.02 & 21.44 \\
\hline Average & & 17.72 & \\
\hline
\end{tabular}

By making a review article concluded:

1- Privatization of the hydrocarbon sector is made in terms of the rescue and keeping as low the public debt, whose rescue is only used as the current solution and not long term. Albania was not ready to undertake this process, where it lacked administrative logistics, legal and long-term experience and strategy of hydrocarbon system in particular and energy in general.

2- As well as any other natural resource, this industry is affected from the global conjuncture. Today its reserves are limited discovered and moreover Albania since 1990 adds no new source. Add new oil reserves are reserves that geological discovered and associated with increased coefficient of oil-extracting existing reserves. Existing contracts and existing rates after 25 years, ,Albania has this source of exhausted. While the future of oil prices is expected to pass the order of $\$ 200$ / barrel in the next 10 years.

3- The privatization of ARMO sha only provides the money of privatization, meanwhile, has created multiple debts where the state has lost over 50 million in the form of uncollected liabilities from state companies and agencies paying tax, and the amount of the share capital in the company. ARMO sha Company provide up to 40 million annual revenue in form of taxes and carry out the work-interception ratio 1 directly to 3 . Today the sight is to the import. The company only has one bank debt, that accumulates around 50 million euros. The company's residual value does not exceed 2 million. So the state won in 2008, 120 million euros this year and has lost no less but 40 million each year.Meanwhile, this company owes the state company on 38 million euros, following debts from 2008 and later.

4- Oil sources are donated and assets of foreign companies represented by the value of reserves, which occupies $90 \%$ of capital, while the value for the Albetroli claims, as manager of this property. In fact by PSC (production sharing contracts), the foreign company is entitled to the cost of oil and oil gain.

5- State policy has led to the reduction and weakening the rural development, employment and ultimately also in status quo tax effects. In essence, the economy has not gained

For the above we recommend:

1- Make the sector eficiense of crude oil processing, setting benchmarks and incentives that this sector to get its brightness back. This is realized through renationalization of this property, turning it into a profitable company and the creation of new competitive conditions and its resale.

2- Reviewing all contracts ALBPETROL sha, in order to protect national interests, today and for the next generation. With the current situation we have decreasing and devaluation of the national currency, the emergence of the capital and opportunities for tax evasion.

3- Building fiscale policies that aim at directing the sale of of crude oil inside Albania and which discourage the exports.

\section{References}

Price Water House Coopers (2011). The Economic Impacts of the Oil and Natural Gas Industry on the U.S. Economy in 2009: Employment, Labor Income, and Value Added, Prepared for the American Petroleum Institute.

OIL and Gas law and taxation Owen Anderson, John Dzienkowski,John lowe, Robert Peroni,David Pierce;Ernest Smith.2004.

Wyoming Heritage Foundation - WHF (2008). Wyoming Oil and Gas Economic Contribution Study.

What Next for the Oil and Gas Industry?John Mitchellwith Valérie Marcel and Beth Mitchell tetor 2012.

Reserves replacement ratio in a marginal oil world: Adequate indicator or subprime statistics? Viti 2011. Gren Peace.

Oil scarcity: What have the past three decades revealed? G.C. Watkins University of Aberdeen and Cerecon Limited, Canada viti 2006.

On the fiscal systems of European countries and the actual debate. Arben Demo (blog). 
The effects of oil price shocks on industrial production: Evidence from some oil-exporting countries. Mohsen Mehdi Sarem Mehrara and Economic Faculty, University of Tehran

Dynamics of petroleum markets in OECD countries in a monthly VAR-VEC model (1995-2007) Mehdi Asali Econometrician, Petroleum Market Analysis Department (PMAD), OPEC Secretariat, Wien, Austria.

On the security of oil supplies, oil weapons,oil nationalism and all that. Robert Mabro Honorary President, Oxford Institute for Energy Studies OPEC Energy Review March 2008

Law no. Dated 7746. 28.07.1993" For Hydrocarbons "(exploration and production) amended:

Law No. 9946 dated 30.06.2008 "On Natural Gas Sector."

Law no. 8450, dated 24.02.1999, "On refining, transportation and marketing of oil, gas and their by-products", as amended.

Regulation of the oil industry, since 1977 (Approved by the Council of Ministers with the document no. 3654, dated 20.12.1976)

Licensing Terms for offshore and onshore Hydrokarbon exploration and exploitation in

Financial Statements of STREAM Oil Vitet $(2010,2011,2012,2013)$

Analysis and discussion of the management of Stream Oil ( vitet 2010,2011,2012,2013)

Consolidadet financials statements (vitet 2004,2005,2006,2007,2008,2009,2010,2011,2012,2013)

International energy statistics

INSTAT Albania

VKM nr 261 date 27/02/2008 'For the treatment of unemployed workers arising from the process of restructuring of ARMO AS ,Tirane and ALBETROL AS Patos

VKM nr 106 date 01/02/2012 "For the treatment of workers who become unemployed in the process of restructuring the society Albetrol Patos

Papers Nr 1333/3 date 28/04/2013 And nr 1133/6 date 04/12/2013 of KLSH(Higher State Control)

Gazeta Shqiptare 'Albpetrol is break the law, we have emergency" Albion Hasani date 26 qershor 2012.

VKM nr 867 date 18/06/2008 "For approval of the final report and award bids for the privatization of ARMO Sha.

Oil industry and the balance of the tax system. Vladimir Mici Dhjetor 2012. Story Conference.UMSH.

Minutes of the general meeting of shareholders dated Sha ARMO data 02/12/2013. 